\title{
DERLEME
}

\section{Menopozal Dönemde Görülen Üriner İnkontinansın Yaşam Kalitesine Etkisi}

\author{
Safiye AŞIKI ${ }^{1}$ Sevil ŞAHIIN ${ }^{2}$
}

\section{$\ddot{O} \mathbf{Z}$}

Menopozal dönem kadın yaşamında birçok etki ve değişime neden olan uzun bir süreç olduğundan önemle ele alınması gereken bir dönemdir. Dünya Sağlık Örgütü’nün tanımına göre menopoz; overlerdeki foliküler aktivitenin sonlanmasına bağlı olarak doğurganlığın ve menstruasyonun geri dönüşsüz şekilde sona ermesidir. Menopoz ile birlikte kadın vücudunda meydana gelen fizyolojik değişiklikler birçok probleme neden olmaktadır. Menopozal dönemde görülen problemler arasında vazomotor semptomlar, genitoüriner sistem sorunları, psikolojik sorunlar ve osteoporoz yer almaktadır. Bireyin yaşam kalitesini ve işlevselliğini etkileyen bu problemler her kadını farklı oranda etkilemektedir. Menopozda görülen genitoüriner sistem değişikliklerine bağlı olarak gelişen üriner inkontinans, kadınların psikolojik, fiziksel, sosyal ve ekonomik iyilik halini dolayısıyla yaşam kalitesini etkilediğinden yaygın bir sağlık sorunu olduğu bilinmektedir. Uluslararası Kontinans Topluluğu'nun tanımına göre üriner inkontinans; istemsiz olarak herhangi bir şekilde idrar kaçırma şikâyetidir. Bu derlemede menopozal dönemde görülen üriner inkontinansın yaşam kalitesine etkisi ele alınmıştır. Hasta ile en çok zaman geçiren meslek grubu olan hemşirelerin menopoz ve üriner inkontinans arasındaki ilişkiyi bilerek yaşam kalitesine etkilerini azaltmaya ve yaşam kalitesini artırmaya yönelik hemşirelik bakımı planlamaları büyük önem arz etmektedir.

Anahtar Kelimeler: Hemşire; İnkontinans; Menopoz

\section{The Effect of Urinary Incontinence Seen During Menopausal Period on Quality of Life}

$$
\text { Safiye AŞIK }{ }^{1} \text { Sevil ŞAHIN }{ }^{2}
$$

\begin{abstract}
Since the menopausal period is a long process that causes many effects and changes in women's life, it is a period that should be handled with importance. According to the World Health Organization, menopause; It is the permanent termination of menstruation and fertility due to the cessation of follicular activity in the ovaries. Physiological changes that occur in the woman's body with menopause cause many problems. Problems seen in the menopausal period include vasomotor symptoms, genitourinary system problems, psychological problems and osteoporosis. These problems affecting the quality of life and functionality of the individual affect each woman differently. Urinary incontinence, which develops due to changes in the genitourinary system seen in menopause, is known to be a common health problem as it affects the psychological, physical, social and economic well-being of women and thus the quality of life. Urinary incontinence according to the definition of the International Continence Society; It is a complaint of involuntary urinary incontinence. In this review, the effect of urinary incontinence seen in the menopausal period on quality of life is discussed. It is of great importance that nurses, who spend the most time with the patient, know the relationship between menopause and urinary incontinence and plan nursing care to reduce their effects on the quality of life and increase the quality of life.
\end{abstract}

Keywords: Incontinence; Menopause; Nurse

${ }^{1}$ Ankara Yıldırım Beyazıt Üniversitesi Sağlık Bilimleri Enstitüsü, Hemşirelik Bölümü, Ankara, Türkiye

${ }^{2}$ Ankara Yıldırım Beyazıt Üniversitesi, Sağlık Bilimleri Fakültesi, Hemşirelik Bölümü, Ankara, Türkiye Sorumlu Yazar: Sevil ŞAHIN

E-posta adresi: sevilsahin1@gmail.comＯRCID No: 0000-0001-7089-6648 Gönderi Tarihi: 09.02 .2021

Kabul Tarihi: 27.02 .2021 


\section{GíRIŞ}

Kadınlar aile ve toplumun temelini oluşturmaktadır. Kadın Sağlığındaki değişimler ve sorunlarda buna bağlı olarak toplum sağlığ1 ile doğrudan ilişkilidir (1). Önceki yıllarda daha düşük sürelerde seyreden yaşam süresinin sağlık alanındaki gelişmeler ve yaşam şartlarındaki iyileşmeler neticesinde arttığı bilinmektedir (2). Türkiye İstatistik Kurumu (TÜİK) 2017- 2019 yılları arasındaki döneme dair raporunda Türkiye'de kadınlar için doğuştan beklenen yaşam süresi 80,7 yıl olarak bildirilmiştir (3). Dünya genelinde menopoza girme yaşı 50-51 yaş aralığında iken $(4,5)$ ülkemizde menopoza girme yaşının $\quad 47-49$ yaş aralığında olduğu bildirilmektedir $\quad(6-8) . \quad \mathrm{Bu} \quad$ veriler 1 şı ğında kadınların, yaşam döngülerinin yaklaşık 1/3' i gibi uzun bir bölümünü menopoz sonrası dönemde geçirdiği ve bu duruma paralel olarak menopozal dönemde karşılaşılacak sorunların öneminin de arttığ1 görülmektedir (9). Kadın hayatı; doğumdan itibaren, çocukluk, ergenlik, erişkinlik, menopoz ve yaşlılık dönemlerinin birbiri ardına devam ettiği evrelerden oluşmaktadır. Her evre kendi içinde farklı özelliklere sahiptir fakat özellikle ergenlik ve menopoz evrelerinin kadın yaşamı üzerinde önemli etkileri mevcuttur. Menopozal dönemin en belirgin özelliklerinden biri de kadının doğal üreme siklusunun sonunu işaret etmesidir $(10,11)$.

Menopozal dönemde görülen değişimler, semptomlar ve sağlık problemleri, ilerleyen yaş ile ilgili anksiyete, doğurma yetisinin kaybedilmesi, beden imajinda meydana gelen değişimler bir araya gelerek yasam kalitesinde büyük ölçüde olumsuz etki yaratmaktadır (12).

Yine menopozda görülen hormonal değişimler, vajinal ve üretral mukozadaki somatik değişimler; üretral kapanma basıncı kaybı ve normal üretrovezikal açıda değişime neden olarak kadınlarda üriner inkontinans (ÜI) gelişmesine sebep olur (13). Demir ve Beji (14) yaptıkları araştırmada menopozdaki kadınların menopoza girmemiş kadınlara göre daha sık Üİ yakınması yaşadıklarını ve menopozal dönemdeki kadınların yaşam kalitesini sıklıkla negatif yönde etkilediğini bildirmektedir.

\section{Menopoz}

Menopoz; overlerdeki foliküler aktivitenin sonlanmasına bağlı olarak doğurganlığın ve menstruasyonun geri dönüşsüz şekilde sona 
ermesidir. On iki ay boyunca her hangi bir patoloji olmaksızın mensturasyon kanamasının olmaması doğal menopoz, overlerin herhangi bir sebeple alınması ile cerrahi menopoz ortaya çıkar (15). Diğer bir tanımda menopoz Royal College of Nursing (16) tarafından, östrojen düzeyinin azalması ile birlikte overlerde folikül fonksiyonunun kaybolmasına bağlı üreme fonksiyonu ve adet kanamasının geri dönüşsüz olarak sonlandığı doğal bir durum olarak tanımlanmıştır.

Kadınlar menopoza yaşamın doğal seyrinde girdikleri gibi iyatrojenik nedenle de menopoza girebilirler. Dünya Sağlık Örgütü (DSÖ) her iki overin cerrahi olarak çıkarılmasını (malign veya benign nedenlerle) veya yumurtalık fonksiyonunun iyatrojenik olarak durdurulması (kemoterapi veya radyoterapi gibi nedenlerle) izleyen menstrüasyonun kesilmesini “İndüklenmiş Menopoz" olarak tanımlar (15).

Menopozal dönemde kadın yaşamında psikolojik, fiziksel ve sosyal yönden birçok değişim yaşadığından menopoz önemle ele alınması gereken bir yaşam evresidir. Klimakterium, kadınların cinsel olgunluk döneminden sonra başlayıp, yaşlılığa kadar süren yaşam dönemine denir. $\mathrm{Bu}$ dönem, premenopoz, perimenopoz ve postmenopoz evrelerini içerir. Bu dönemde diğer yaşam dönemlerinde olduğu gibi biyolojik, psikolojik ve sosyal değişimler görülür. Klimakterik dönem 40-45 yaşlarında başlar ve 65 yaşına kadar sürebilir. Menopoz; yaş, ırk, sosyoekonomik durum, kalitsal faktörler, ilk mensturasyon yaşı, evlilik ve iş durumu, genetik faktörler, kontraseptif yöntem seçimi, beslenme, tütün ürünleri kullanımı, gebelik sayısı, psikolojik faktörler gibi birçok faktörden etkilenmektedir (17).

Menopoz; kadında meydana getirdiği değişiklikler nedeniyle yaşam kalitesi üzerinde birçok etkiye sahiptir. Kadının menopoz ile birlikte gelen değişiklikler ve semptomlar ile başa çıma derecesi, bu dönemde yaşamına ilişskin doyum hissi ve mutluluk durumu yaşam kalitesini etkileyen faktörlerdir (9).

Türkiye Nüfus ve Sağlık Araştırması (TNSA) 2018 verilerine göre ülkemizde 30-49 yaş kadınların menopoza girme oranı toplam nüfusa göre $\% 10.3$, 48-49 yaşında menopozda olan kadınların oranı ise \%45.1'dir (18). Menopoz gelişmiş ülkelerde daha 
ileri yaşta görülür iken; gelişmekteki ülkeler ve gelişmemiş olan ülkelerde daha erken yaşlarda görülebilmektedir. İnsan ömründe beklenen yaşam süresinin artması, kadınların yaşamının yaklaşık üçte biri gibi büyük bir bölümünü menopozal dönemde geçiriyor olması, menopozal dönemin ve bu dönemde ortaya çıkan psikolojik, fizyolojik, sosyal değişimlerin önemini artırmakta dikkatle ele alınmasını gerektirmektedir. Çünkü kadınların beklenen yaşam sürelerinin uzaması menopozal dönem değişikliklerine daha uzun süre maruz kalacakları sonucunu doğurmaktadır (19).

Menopozal dönemde meydana gelen değişimler, menopoz semptomları olarak adlandırılır. Menopoz semptomlarının başlıca nedeni; overlerin aktivitesini kaybetmesi ile birlikte vücuttaki östrojen düzeyinin azalmasıdır $\mathrm{Bu}$ semptomlar, kadınlarda erken ve geç dönem semptomları olarak sınıflandırılabilir. Erken dönemde üriner sistem sorunları, psikolojik sorunlar ve seksüel problemler görülürken; ilerleyen dönemde osteoporoz, ürogenital farklılaşmalar, kalp damar sistemi hastalıkları görülmektedir. Tüm bu belirti ve değişimler, kadın sağlığını negatif yönde etkileyerek yaşam kalitesinde azalmaya sebep olmaktadır (20).

Menopozal dönemde kadınlarda gece terlemesi, sıcak basması, çarpıntı, uyku problemleri, kas ve eklem problemleri, kardiyovasküler sistem hastalıkları gibi somatik yakınmalar, sinirlilik, yorgunluk, halsizlik, depresyon, unutkanlık, konsantrasyon problemleri gibi psikolojik semptomlar görülebilmektedir. Bu semptomlarla birlikte vulvovajinal atrofi ve kuruluk, disparoni, cinsel istekte azalma dahil genitoüriner semptomlar özellikle; sık idrara çıkma, ani idrara sıkışma hissi ve noktüri gibi alt üriner sistem semptomları da menopozal dönemde daha sık görülmektedir (2022).

Menopoz ile birlikte ortaya çıkan üreme yeteneğinin kaybı kadınların birçoğu tarafından kadınlığın ve çekiciliğin yitirilmesi olarak algılanmakta ve bu durum kadının cinsel sağlığını olumsuz etkilemektedir. Menopoz döneminde yaşanan bu şikâyetler her kadını farklı düzeyde etkilemekle birlikte kadınların çoğunluğunda yaşam kalitesini düşürdüğü bilinmektedir. Menopozda görülen genitoüriner sistem değişikliklerine bağlı olarak gelişen üriner 
inkontinans, kadınların ve diğer aile üyelerinin psikolojik, bedensel, sosyal ve ekonomik iyilik halini etkileyen ve sı görülen bir sağlık problemidir (13).

\section{Üriner İnkontinans}

Uluslararası Kontinans Topluluğu' nun (ICS) tanımına göre üriner inkontinans (ÜI); istemsiz olarak herhangi bir idrar kaçırma şikâyetidir. Üİ tipleri stres, urge, miks, noktüri, postural, koital, istemsiz inkontinans olarak gruplandırılmaktadır ve stres üriner inkontinans diğer tiplere göre daha fazla görüldüğü bildirilmiştir $(23,24)$.

Menopozda görülen hormonal sistem değişiklikleri, vajen ve üretra mukoz membranlarındaki somatik değişimler; üretrada kapanma basıncinın yitirilmesi ve normal üretrovezikal açıda değişime neden olarak kadınlarda Üİ gelişmesine sebep olur (13).

Üİ ile ilgili risk faktörleri yaş, doğum sayısı, menopoz, obezite, vajinal yolla doğum ve histerektomi öyküsüdür. Şentürk ve ark. (13) postmenopozal kadınlarda Üİ görülme sıklığı ve risk faktörü olan vajinal doğum ve hormon replasman tedavisi uygulamanın etkilerinin belirlemek amacıyla yaptıkları çalışmada menopozlu kadınlar arasındaki Üİ prevalansını \% 45.3 olarak saptanmışlardır.

Irwin ve ark. (25) yaptıkları çalışmada 2008 yılı dünya nüfusunun (4.3 milyar) minimum \%21.5'inde Üİ görüldüğü, 2018 y1lına kadar bu oranın \%21.6 (423 milyon) olmasının beklendiği belirtilmektedir. Ülkemize baktığımızda üriner inkontinans sıklığ1 \%21.3-44.8 aralığında değiştiği görülmektedir $(26,27)$. Literatürde menopozal dönemde üriner inkontinans görülme sıklığının arttığ1 belirtilmektedir $(26,28)$. Postmenopozal dönemde Üİ görülme sıklığının yüksek olduğu ve kandaki düşük östrojen seviyesinin buna neden olduğu iddia edilmektedir. Uterusu tutan kardinal ve uterosakral bağlardaki östrojen reseptör yoğunluğunun menopoz sonrası dönemde azalmaktadır. $\mathrm{Bu}$ nedenle yapılan çalışmalarda da menopoza girenlerde Üİ sıklığında artış olduğu bulunmuştur $(13,26,29)$. Üİ kadınlarda utanç ve kendine güvensizlik hissine neden olarak, psikolojik iyilik halini azaltıcı yönde etki oluşturmaktadır. Üİ bedensel, sosyal, psikolojik ve ekonomik etkileri nedeniyle kadınların yaşam kalitesini negatif yönde etkilediğinden Üİ için etiyolojik faktörlerin bilinmesi, hastaların bu 
hususta eğitilmesi ve erken dönemdeki girişimler ile Üİ gelişimi azaltılarak ve kadınların genel sağlık düzeyleri ve yaşam kaliteleri artırılabilmektedir (29). Findik ve ark. (30) 761 hasta ile yaptıkları çalışmada menopoza giren kadınlarda girmeyenlere göre hem stres ÜI, hem de urge Üİ görülme sıklığının arttı̆̆ 1 , Dinç ve ark. (31) yaptığ1 çalışmada premenopoz dönemdeki kadınlarda Üİ görülme sıklığg $\% 9$ iken, menopoz sonras1 dönemdeki kadınlarda \%50 olup genel görülme sıklığ1 \%29.6 olarak bulunmuştur. Aynı çalışmada menopoz sonrası 50-64 yaş grubu kadınların daha fazla Üİ sorunu yaşadıkları saptanmıştır.

Menopoz ile Üİ arasındaki ilişkinin kadınların menopoza girme yaşına bağlı olduğu bildirilmektedir (32). Menopozdaki ilk birkaç yil içinde östrojen hormonundaki azalma belirgin şekilde etki yaratmayabilir. Fakat yaşın artması ile birlikte menopoz süresinin de artması sonucu östrojenin git gide azalmasına bağlı etkilerin görülmeye başladığı ve Üİ görülme sıklığının arttığ1 bildirilmektedir (32). Kadınlar, üriner inkontinansı yaşın ilerlemesi ile birlikte normal bir süreç olarak görmekte, sağlık kuruluşuna başvurmadan bu sorun ile kendileri baş etmeye çalışmaktadırlar (33). Güvey’in (34) premenopoz ve postmenopozal dönemdeki geriatri hastalarının jinekoloji kliniğine başvurma sebeplerini karşılaştırmak amacıyla yaptığı bir çalışmada 25 premenopozal ve 25 postmenopozal ileri yaş kadın hasta retrospektif olarak incelenmiştir. Geriatrik yaş grubunda tüm jinekolojik problemlerin görülebildiği fakat menopoz ile gelişen hipoöstrojenemiye bağlı gelişen semptomların daha sık görüldüğü bulunmuştur. Çalışmada sonucunda postmenopozal dönemdeki gruptaki kadınların \%20' sinde üriner inkontinans görülürken, premenopozal gruptaki hastalarda üriner inkontinans görülmediği dikkat çekmiştir (34).

Üİ tedavisinde davranışsal ve nonfarmakolojik tedaviler, farmakolojik tedaviler ve cerrahi tedavi yöntemleri kullanılmaktadır. Nonfarmakolojik ve davranışsal tedavi yöntemleri yaşam tarzı değişiklikleri, mesane eğitimi ve pelvik taban kaslarının egzersizleri olarak sıralanabilir. Yaşam tarzı değişiklikleri; obez bireylerin kilo vermesi, diyet değişimi, kafein ve varsa fazla sıvı tüketiminin düşürülmesi şeklinde tavsiyeleri içerir (35). 
Küçükkaya ve ark. (36) pelvik taban problemlerinde başvurulan geleneksel ve tamamlayıcı tedavi yöntemlerinden; pelvik taban kas egzersizleri, akupunktur, yoga, abdominal egzersizler, masaj, pilates ve Gua Sha' nın başvurulan yöntemler olduğunu belirtmişlerdir. Üİ'ın geleneksel ve tamamlayıcı tedavisinde tüm bu tedavi yöntemlerinin kullanılabildiği belirlenmiştir (36).

\section{Yaşam Kalitesi}

Sağlığın değerlendirilmesinde ele alınan geleneksel belirteçler olan hastalık, ölüm, beklenen yaşam süresi gibi göstergeler bireylerin sağlık seviyesini belirlemekte yeterli olmamaktadır. $\mathrm{Bu}$ yüzden günümüzde yaşam kalitesi kavramı gündeme gelmiştir. Yaşam kalitesi, bireyin sağlık durumu ile bireysel iyilik halini de içine alan daha geniş bir kavramdır. DSÖ yaşam kalitesinin tanımını "bireylerin içinde yaşadıkları kültür ve değerler sistemindeki kendi yaşam algıları” olarak yapmıştır. Menopozal dönemde fizyolojik, psikolojik ve sosyal yönden birçok farklılaşma oluştuğundan, kadının yaşam tarzı ve dolayısıyla yaşam kalitesi ciddi ölçüde etkilenmektedir (37).
Erkin ve ark. (37) menopozun kadın yaşam kalitesine etkisini araştırdıkları çalışmada, menopozdaki kadınların menopoz semptomları ve ortaya çıkan şikâyetler ile iyi baş edemediklerini ve bu kadınların yaşam kalitesinin negatif yönde etkilediğini bildirmektedir.

Abay ve Kaplan (38) yaptıkları çalışmada, menopozal dönemin kadınların yaşam kalitesini negatif yönde etkilendiğini, kadınların yaşam kalitelerinin orta seviyede olduğunu bulmuşlardır. Ayrıca pozitif menopoz algısı arttıkça ve menopoza dair sağlık problemi yaşama algısı azaldıkça yaşam kalitesinin yükseldiğini, cerrahi menopoza giren kadınların cinsel yaşam kalitesinin azaldığ $ı n ı$ bildirmişlerdir (38).

Elazim ve ark. (39) kadınların menopoz döneminde önemli seviyede menopoz belirtisi gösterdiğini, menopoz sonrası dönemdeki kadınların fiziksel ve vazomotor belirtileri menopoza geçiş evresindeki kadınlara göre daha çok yaşadığını ve postmenopozal dönemdeki kadınların yaşam kalitesinin düştüğünü bildirmişlerdir.

Abay ve Kaplan (12) yaptıkları çalışmada doğumdan beklenen yaşam süresinin artması ile birlikte kaliteli bir hayat sürdürme arzusu ve 
menopozal dönemin kadın hayatının 3 te 2 sini kapsamas1, menopoza özgü yaşam kalitesi kavramının ehemmiyet kazanmasına sebep olduğunu belirtmektedir. Yine aynı çalışma sonucunda menopozda yasam kalitesini yükseltebilmek için ilk planda doğru tanı koyulması gerektiğini bunun için de uygun ölçme aracının yani menopoza özgü geliştirilen yaşam kalitesi ölçeklerinin kullanılması gerektiği önerilmektedir (12).

Yılmaz ve ark.'nın (29) üriner inkontinanslı kadınların yaşam kalitesi düzeyini saptamak amacıyla yaptığg çalışmada Üİ'ı olan kadınların \%62.0'sinin menopozda olduğu bulunmuştur. Amanak ve ark. (40) Üİ olan ve olmayan kadınların yaşam doyumu ve sosyal kayg1 düzeylerinin karşılaştırılması amacıyla yaptıkları çalışmada Üİ olan kadınların olmayan kadınlara göre Yaşam Doyumu Ölçeği puan ortalamalarının daha düşük olduğu ve bu farkın istatistiksel olarak anlamlı olduğu ortaya koyulmuştur. Üİ olan kadınların, olmayanlara göre yaşam doyum seviyelerinin daha düşük, sosyal kaygı seviyelerinin ise daha yüksek olduğu sonucuna erişilmiştir. Çalışma sonucunda özellikle birinci basamak sağlık hizmetlerinde çalışanların, ÜI'ın kadın hayatındaki olumsuz neticelerini bilerek; gelişmesini önleme, kadınları uygun sağlık kurumlarına yönlendirme, Üİ yaşayan kadınların tanı ve tedavi hususlarında aktif şekilde görev yapması gerektiği vurgulanmaktadır(40).

Aoki ve ark. (41) çalışmasında; bir kadının hayatı boyunca mesane fonksiyonlarının birçok faktörden etkilenerek Üİ semptomları iyi ya da kötü yönde değişebildiğini, kronik bir durum olarak Üİ ile yaşayan kadınların, tedavi önerileri hakkında karamsar hissedebileceklerini belirtmişlerdir. Çalışmada bütün Üİ türlerinin kadın için son derece rahatsız edici olduğu, hastanın tedaviye katılma isteği tedaviden alınacak yarar seviyesi belirlemekte etkili olduğu, yaşam kalitesinin değerlendirilmesinin idrar kaçırmanın birey üzerindeki etkisini belirleme ve tedavilerin yararını değerlendirmede önemli bir faktör olduğu vurgulanmıştır (41).

\section{Hemşirenin Rolü}

Kadınların yaşam kalitesini birçok yönden olumsuz etkileyen Üİ probleminin ortaya çıkmasını koruyucu sağlık hizmeti ile engelleme ve var olan inkontinans probleminin ise en erken evrede belirlenerek hastaya uygun bakımın planlanması 
hemşirelik bakımının temel amacıdır. Menopozal dönemde doğru ve zamanında planlanan etkili hemşirelik girişimleri kadın sağlığının ve yaşam kalitesinin geliştirilmesine önemli katkılar sağlayacaktır. Hemşireler sağlık hizmeti sunmak için kadınlara ulaşmada büyük bir öneme sahiptir. Üİ’ın önlenmesi, erken tespit edilmesi, doğru değerlendirmesi ve takibinde hemşirelere önemli görevler düşmektedir (42).

Son zamanlarda özellikle ürojinekoloji kliniklerinde çalışan, Üİ hakkında eğitim alan hemşireler, Üİ önlenmesi ve tedavisinde rehberlik, danışmanlık, klinisyen, araştırmacı, destekleyici ve organize edici olma rolleri ile ön planda yer almaktadır. Hemşireler multidisipliner sağlık hizmeti anlayışı ile üstlendikleri görevlerle kadınların yaşam kalitesini azaltan Üİ probleminin önlenmesine ve ortadan kaldırılmasına yönelik büyük katkılarda bulunmaktadırlar $(42,43)$.

Üİ’n normal ve sağlıklı bir durum olmadığı ve erken dönemde doktora başvurulmasının iyileşme sürecini hızlandırabileceği hususlarında toplumun farkındalığg sağlanmalıdır. Kontinans hemşireleri beslenme alışkanlığının düzenlenmesi, vücut ağırlığ1 kontrolü, tütün ürünlerini bırakma, egzersiz, boşaltım alışkanlıklarının düzenlenmesi ile yaşam tarzı değişiklikleri gibi hususlarda kişiye ve yakınlarına sağlığı korumaya ve geliştirmeye dair bilgilendirme görevinde önemli konumdadır (44). Hemşireler tarafindan kadınlarda Üİ konusunda farkındalık oluşturmaya yönelik girişimler planlanmalı, Üİ'1 önlemek için yapılabilecekler ve gerektiğinde tedavisi için başvurulacak sağlık kuruluşları hakkında bilgi verilmelidir (42). Menopozal dönemde semptomları erken tespit etmek, var olan semptomlara dair uygulanacak eğitim ve rehberliği planlayarak kadınlara sağlık bilinci edindirmek, menopozal evrede kadının karşılaşacağı bedensel, duygusal ve sosyal problemlerle mücadele etmesine yardımcı olacaktır. Hemşirelerin menopoz döneminde ortaya çıkabilecek semptomlar hususunda bilgi düzeylerinin yükselmesi koruyucu sağlık hizmeti geliştirme ve uygulamalarına firsat yaratacaktır (45).

\section{SONUÇ}

Kadın hayatında ciddi birçok değişime sebep olan menopoz dönemi bir hastalık hali değil, yaşamın doğal seyrindeki bir süreçtir. Kadınlar Menopoza bağlı ortaya çıkan semptomları nasıl yöneteceği ve 
menopoza bağlı ortaya çıabilecek

komplikasyonları nasıl önleyebileceği konularında

eğitilmelidir. Hemşireler bütüncül yaklaşım ile planlayacakları bakım ve eğitimler ile menopozal dönemdeki kadınların sağlığını ve yaşam kalitesini geliştirmede önemli bir göreve sahiptir. Yaşam kalitesi, hemşirelik bakımının planlamasından değerlendirilmesine kadar olan süreçte önemli bir parametredir. Hemşireler menopozal dönem, menopoza ilişkin görülebilecek semptomlar, komplikasyonlar ve yaşam kalitesi üzerine etkileri konusunda güncel bilgilere sahip olmalı, gelişmeleri takip etmeli, kadınlara yaşam kalitesini sürdürmeye ve artırmaya yönelik danışmanlık yapabilmelidir. Menopozal dönemde artış gösteren Üİ’ın erken dönemde tespit edilmesi, buna yönelik verilecek eğitim ve rehberlik hizmetlerinin doğru planlanması ve böylece kadınlarda sağlıklı yaşam bilinci oluşturma konularında hemşirelere büyük rol düşmektedir. Menopozal dönemdeki kadınlarda uygulanacak hemşirelik yaklaşımı olarak; hemşireler tarafindan kadınlara pelvik taban yapısını koruyan ve güçlendiren sağlık davranışları öğretilmeli, olumlu davranış değişikliği geliştirilmeli, Üİ açısından riskli gruplar taranmalı, gerektiğinde menopozal dönemde inkontinans problemi olan kadınlar ürojinekoloji kliniklerine yönlendirilmelidir. Ülkemizde ürojinekoloji alanında çalışan hemşire sayısının artırılması, ürojinekoloji hemşireliği eğitim programları düzenlenerek menopozal dönemdeki kadınlarda üriner inkontinansın tespit, takip ve tedavisinde hemşirelere daha aktif rol verilebileceği önerilmektedir.

\section{KAYNAKLAR}

1. Orhan İ, Yağmur Y. Menopozal dönemde sağlıklı yaşam biçimi davranışları yaşam kalitesi ve motivasyonel görüşmeler. İnönü Üniversitesi Sağlık Hizmetleri Meslek Yüksek Okulu Dergisi. 2020; 8(2):496-505.

2. Özkurt V. Bakım sürecinde geronteknolojinin etkin kullanımı: Bakım verenlerin algılarına ilişkin nitel bir çalışma. Senex: Yaşlılık Çalışmaları Dergisi. 2019; 3(3):54-59.

3. Türkiye İstatistik Kurumu. Hayat tabloları 2017-2019 [Internet]. 2020. [cited 2021 Feb 1]. Available from: https://tuikweb.tuik.gov.tr/PreHaberBultenleri.do?id=33711

4. Taşkın L, editör. Doğum ve kadın sağlığı hemşireliği. Genişletilmiş XIII. Baskı. Ankara: Akadmisyen Tıp Kitabevi; 2016. p. 671-687.

5. Royal College of Obstetricians and Gynaecologists [Internet]. 2020. [cited 2021 Jan 5]. Available from: https://www.rcog.org.uk/en/patients/menopause/menopause---alife-stage/

6. Yangın HB, Kukulu K, Ak Sözer G. The perception of menopause among Turkish women. Journal of Women \& Aging. 2010; 22(4):290-305.

7. Gözüyeşil E, Başer M. Menopozal dönemde yaşanan vazomotor yakınmaların günlük yaşam aktiviteleri üzerine etkisi. Anadolu Hemşirelik ve Sağlık Bilimleri Dergisi. 2016; 19(4):1-8.

8. Türk Jinekoloji ve Obstetri Derneği (TJOD). TJOD'den Açıklama Dünya Menopoz Günü [Internet]. [cited 2021 Jan 4]. Available from: https://www.tjod.org/tjodden-aciklama-dunya-menopozgunu/

9. Fışkın G, Şahin N, Güler K. Menopozal dönemdeki kadınların bu yaşam dönemine ilişkin bakış açılarının kalitatif analizi. G.O.P Taksim E.A.H. JAREN. 2017; 3(3):122-8.

10. Bekmezci E, Altuntuğ K. Menopoz ile ilişkili semptomlara yönelik kanıta dayalı uygulamaların incelenmesi. Genel Sağlık Bilimleri Dergisi. 2020; 2(3):167-74.

11. Daley A, Stokes-Lampard H, Thomas A, MacArthur C. Exercise for vasomotor menopausal symptoms. Cochrane Database of Systematic Reviews. 2014, Issue 11. Art. No.: CD006108. 12. Abay H, Kaplan S. Menopause-specific quality-of-life scales: Review of literature/ Menopoza özgü yaşam kalitesi ölçekleri: Literatür incelemesi. Journal of Education and Research in Nursing. 2020; 17(1):94-102. 
13. Şentürk Ş, Kara M. Menopoz dönemindeki kadınlarda üriner inkontinans prevalansı ve risk faktörleri. Van Tıp Dergisi. 2010; 17(1):7-11.

14. Demir S, Beji NK. Üriner inkontinanslı kadınlarda yaşam kalitesi ve sağlık arama davranışları. FN Hem. Derg. 2015; 23(1):23-31.

15. International Menopause Society. Menopause Terminology [Internet]. 2018 [cited 2020 Dec 22]. Available from: http://www. imsociety.org/menopause_terminology.php.

16. Royal College of Nursing. Menopause RCN guidance for nurses, midwives and health visitors [Internet]. 2020 [cited $2021 \mathrm{Feb} 1]$. Available from: https://www.rcn.org.uk/professionaldevelopment/publications/rcn-menopause-guidance-for-nursesmidwives-and-health-visitors-uk-pub-0093326

17. Saydam BK, editör. Olgularla jinekolojik hastalarda bakım. I. Bask1. Ankara: Nobel Tip kitabevleri; 2015. p. 200-208.

18. Hacettepe Üniversitesi Nüfus Etütleri Enstitüsü. Ana Rapor [Internet]. 2018 [cited 2021 Feb 1]. Available from: http://www.hips.hacettepe.edu.tr/tnsa2018/rapor/TNSA2018_ana_ Rapor.pdf

19. Takashi TA, Johnson KM. Menopause. Med Clin N Am. 2015; 99:521-34.

20. Bacon JL. The menopausal transition. Obstet Gynecol Clin. 2017; 44(2):285-96.

21.. Roberts H, Hickey M. Managing the menopause: an update. Maturitas. 2016; 86:53-8.

22. İlkin E, Şahan Ö, Akarsu RH, Akarsu G. Menopozal kadınlarda egzersizin fizyolojik etkileri: Bir sistematik derleme. Akdeniz Spor Bilimleri Dergisi. 2020; 3(2):373-85.

23. Haylen BT, Ridder D, Freeman RM, Swift SE, Berghmans B., et al. An international urogynecological association (IUGA)/international continence society (ICS) joint report on the terminology for female pelvic floor dysfunction. Neurourol Urodyn. 2010; 29:4-20.

24. Özkan SA, Bilgiç D, Beji NK. Türkiye'de hemşirelik alanında üriner inkontinansla ilgili yapılan lisansüstü tezlerin incelenmesi. ACU Sağlık Bil Dergisi. 2019; 10(2):201-10.

25. Irwin DE, Kopp ZS, Agatep B, Milsom I, Abrams P. Worldwide prevalence estimates of lower urinary tract symptoms, overactive bladder, urinary incontinence and bladder outlet obstruction. Bri J Urol Int. 2010; 108:1132-9.

26. Terzi H, Terzi R, Kale A. 18 Yaş üstü kadınlarda üriner inkontinans sıklığ 1 ve etkileyen faktörler. Ege Tıp Dergisi. 2013; 52(1):15-19.

27. Ünsal A, Tözün M, Arslantaş D. Eskişehir ili Beylikova ilçe merkezinde 20 yaş ve üzeri kadınlar arasında üriner inkontinans, ilişkili faktörler ve depresyon. TAF Prev Med Bull. 2013; 12:23142.

28. Öztürk GZ, Toprak D, Basa E. 35 yaş üzeri kadınlarda üriner inkontinans sıklı̆̆ ve etkileyen faktörlerin değerlendirilmesi. Şişli Etfal Hastanesi Tıp Bülteni., 2012; 46:170-6.

29. Yılmaz E, Muslu A, Özcan E. Üriner inkontinanslı kadınlarda yaşam kalitesi. ERÜ Sağlık Bilimleri Fakültesi Dergisi. 2014; 2(2), 1-14.

30. Findık RB, Unluer AN, Şahin E, Bozkurt OF, Karakaya J, Unsal A. Urinary Incontinence in women and its relation with pregnancy, mode of delivery, connective tissue disease and other factors. Adv Clin Exp Med. 2012; 21:207-13.

31. Dinç A, Özer NE. Premenopoz ve menopozal dönemdeki kadınlarda üriner inkontinans örülme sıklığı ve risk faktörlerinin incelenmesi. Gümüşhane Üniversitesi Sağlık Bilimleri Dergisi. 2019; 8(2):1-9.

32. Pérez-López FR, Cuadros JL, Fernández-Alonso AM, Chedraui P, Sánchez-Borrego R, Monterrosa-Castro A. Urinary İncontinence, related factors and menopause-related quality of life in mid-aged women assessed with the Cervantes Scale. Maturitas. 2012; 73(4):369-72.

33. Subramaniam J, Eswara S, Yesudhason B. Association of urinary tract infectionin married women presenting with urinary incontinence in a hospital based population. J Clin Diag Res. 2016; 10:10-3.

34. Güvey H. Jinekoloji polikliniğine başvuran geriatrik hastalardaki problemlerin premenopozal dönemdeki hastalarla kıyaslanması. Konuralp Tip Dergisi. 2020; 12(1):144-7.

35. Öztaş S. Üriner İnkontinans. İn: Çakmak BD, editör. Jinekolojide Pratik Bilgiler. Lyon: Livre de Lyon; 2020. p. 221-238. 36. Küçükkaya B, Kahyaoğlu SH. Pelvik taban bozukluklarında kullanılan geleneksel ve tamamlayıcı tedaviler. Ordu Üniversitesi Hemşirelik Çalışmaları Dergisi. 2020; 3(1):44-53.

37. Erkin Ö, Ardahan M, Kert A. Menopoz döneminin kadınların yaşam kalitesine etkisi. Gümüşhane Üniversitesi Sağlık Bilimleri Dergisi.2014; 3(4):1095-113.

38. Abay H, Kaplan S. Menopozal dönem yaşam kalitesini nasıl etkiliyor? Ankara Sağlık Bilimleri Dergisi. 2015; (1-2-3):1-23.

39. Elazim HA, Lamadah SM, Zamil LGA. Quality of life among of menopausal women. Journal of Biology. Agriculture and Healthcare. 2014; 4(11):78-88.

40. Amanak K, Sevil Ü. Üriner inkontinansı olan ve olmayan kadınların yaşam doyumu ve sosyal kaygı düzeylerinin karşılaştırılması. Düzce Üniversitesi Sağlık Bilimleri Enstitüsü Dergisi. 2020; 10(2):217-22.

41. Aoki Y, Brown HW, Brubaker L, Cornu JN, Daly JO, Cartwright R. Urinary incontinence in women. Nature reviews Disease primers. 2017; 3(1):1-20.

42. Öz Ö, Altay B. Üriner inkontinans risk faktörleri ve hemşirelik yaklaşımı. İnönü Üniversitesi Sağlık Bilimleri Dergisi. 2017; 6(1):34-37.

43. Topuz Ş. Üriner inkontinans ve cinsellik. Balikesir Saglik Bil Derg. 2015; 4(1).

44. Yıldırım ÖÖ, Avci İA. Üriner inkontinanslı hastalarda bakımın yönetimi ve hemşirelik. Hacıhasanoğlu RA, editör. Kronik hastalıklarda bakımın yönetimi ve hemşirelik. 1. Baskı. Ankara: Türkiye Klinikleri; 2019. p. 60-5.

45. Çelik AS, Pasinlioğlu T. Klimakterik dönemde yaşanan semptomlar ve hemşirenin rolü. Erciyes Üniversitesi Sağlık Bilimleri Fakültesi Dergisi. 2013; 1(1):50-56. 